\title{
Is there a Moral Right to Vote?
}

\author{
Ludvig Beckman ${ }^{1}$ (D)
}

Accepted: 3 July 2017

(C) The Author(s) 2017. This article is an open access publication

\begin{abstract}
The question raised in this paper is whether legal rights to vote are also moral rights to vote. The challenge to the justification of a moral right to vote is that it is not clear that the vote is instrumental to the preservation of some critical interest of the voter. Because a single vote has 'no impact' on electoral outcomes, the right to vote is unlikely to serve the interests of the individual. The account developed in this paper holds that moral voting rights can be justified once we acknowledge that voting by a sub-set of citizens is among the necessary preconditions for democratic institutions making a significant difference to their collective interests. The justification of a moral right to vote does not, then, apply to each individual citizen but only to a sub-set of them. In order to justify inclusive moral voting rights, the further consideration must be added that individuals have critical interests in public recognition of equal status. An inclusive moral right to vote accordingly depends on both collective interest in the outcomes of democratic institutions and on individual interest in equal recognition.
\end{abstract}

Keywords Moral rights $\cdot$ Right to vote $\cdot$ Collective interests $\cdot$ Democracy

\section{Introduction}

The legal right to vote in general elections is widely recognized as a necessary requirement for democracy (Dahl 1989). ${ }^{1}$ Yet, to accept the importance of legal voting rights is not to provide reasons for the existence of a moral right to vote. In order for a moral right to vote to exist, it must be explicable in terms consistent with the requirements for moral rights. Following the interest-theory, A has the moral right to $\mathrm{X}$ if and only if holding others under a duty to secure $\mathrm{X}$ 'makes a significant difference for the protection or promotion' of the critical interests of A (Raz 1986, p.183; Lyons 1969). In order for A to have the moral right to vote, we should accordingly be able to show that holding others under duties towards $\mathrm{A}$ is instrumental to the

\footnotetext{
${ }^{1}$ The vote can be treated as an element of democracy rather than a mere practical requirement. Yet, legal voting rights are not required by definition since democracy can be practices without such rights being legally protected.
}

Ludvig Beckman

ludvig.beckman@statsvet.su.se

1 Department of Political Science, Stockholm University, 10691 Stockholm, Sweden 
protection of A's interests. Moreover, the interests preserved by the right to vote must be critical in the sense of being important enough to justify the imposition of duties on others.

Now, it is disputable that the right to participate in elections advances the 'critical' interests of the voter. In large-scale representative democracies, the significance of a single vote is negligible as testified by estimates of the probability that a single vote determines elections. From the point of view of the individual voter, the instrumental value of casting a ballot in national elections is 'close to zero' (Geys 2006). Based on similar observations James Griffin (2008, p.247) remarks that the vote does 'practically nothing to protect one's being able to pursue one's chosen ends'.

The claim that the vote is not instrumental to the critical interests of the voter (whatever they may be) has immediate implications for the notion of a moral right to vote. Given the condition that moral rights exist only when they serve the critical interests of the rights-bearer, the conclusion is that voting cannot be a moral right. Jacob (2015) has helpfully termed this the 'no-impact' objection. The point is not that elections are of no import to individual members of the polity but that there is no basis for a duty to secure the right to vote for any single person if the opportunity to vote does not advance the critical interests of the rights-bearer.

Moral rights are not necessarily best understood on the basis of the interest-theory, however. And it is conceivable that a case for a moral right to vote can therefore be made by appeal to another theory of moral rights. Following one view, moral rights protect choices in some specified domain (the choice theory). Another view is that moral rights protect the status of the person as a particular kind of being (the status-theory) (Kamm 2002). However, this inquiry is assuming the correctness of the interest-theory of moral rights. The question then is whether moral voting rights can withstand the no-impact objection on terms consistent with the interest-theory of rights?

The first three sections of the paper examine arguments for moral voting rights corresponding to three different views about the interests preserved by the right to vote: interests in the outcomes of democratic institutions, interests in the recognition conferred by democratic institutions and interests in participation together with others. I contend that these arguments fail to meet the standards of the interest-based theory since none of them successfully explains why the right to vote serves to preserve the critical interests of the individual voter. The fourth section of the paper argues that a moral right to vote can be defended by showing that it is instrumental to collective interests. Although the critical interests of individuals, taken separately, are not significantly served by democratic institutions, the fact of living in a democracy is making a significant contribution to the critical interests of individuals in the aggregate (collective interests). Based on this observation, I argue that the moral right to vote is justified by it being instrumental to the collective interests of citizens in the outcomes associated with democratic institutions. In the final discussion, the paper argues that inclusive moral voting rights depends on the additional claim that individuals have interests in equal public recognition since inclusion is not necessary in order for democratic institutions to promote collective interests. Individual interests in equal recognition, in conjunction with collective interests in the outcomes of democratic institutions, are thus sufficient for inclusive moral rights to vote. What is new and original about the position developed here is that moral voting rights are justified only by invoking the combination of individual and collective interests.

\section{Interests in Outcomes}

A familiar argument in favor of democracy is that it promotes 'common interests' and 'human development' (Weale 2007, p.68; Dahl 1989, p.311). Indeed, democracy is associated with 
various outcomes of importance. While the pattern and strength of the causal relationship remains subject to scholarly debate, robust evidence exists for a positive connection between democracy and a range of precious goods such as public health and public education (Mesquita et al. 2003), peaceful relations with other democracies (Dafoe et al. 2013) and protection of human rights to bodily integrity (Davenport 2004). In addition, there is a connection between democracy and economic growth (Acemoglu et al. 2014) and human development (Gerring et al. 2012). These public and private goods are of critical interests to individuals, in so far as they are necessary for the development of basic capabilities (Robeyns 2009 , p.40). Hence, since voting rights are among the essential requirements of democracy, the right to vote does seem to contribute to the preservation of critical individual interests. These observations should be sufficient to ground moral voting rights, given the interest-theory of rights. If duties to secure opportunities to vote in democratic elections contribute directly to the preservation of the critical interests of citizens, it follows that they are morally entitled to vote.

In fact, Thomas Christiano (2011) has developed an argument in defense of a human right to democracy that builds on the positive effects of democratic institutions on the critical interests of citizens. Specifically, he argues that a moral human right to democracy derives from the observation that democratic institutions significantly reduces the risk of the state engaging in repression of the kind that constitutes violations of human rights to bodily integrity. Because democracy preserves human rights that represent protections of critical interests, there should be a (human) moral right to democracy.

However, given the interest-theory of moral rights, the argument developed above and defended by Christiano seems inadequate in two respects. The interest-theory holds that A has a moral right $\mathrm{X}$ if and only if $\mathrm{X}$ is shown to contribute significantly to the critical interests of $\mathrm{A}$. The problem with the notion of a moral right to democracy grounded in the instrumental significance of democratic institutions, is that it is unclear that democratic institutions make a significant difference to the critical interests of individual citizens. Moreover, it is not clear that a moral right to vote is necessary to enjoy the positive benefits of democratic institutions. There might not be a moral right to vote then, even if there is a moral right to democracy.

The first worry is that the capacity of democratic institutions to provide private and public goods does not have a significance enough effect on the critical interests of individuals. Although what should count as 'significant enough', following the interest-theory, is to some extent unclear, it is arguably the case that a moral right makes a significant contribution to the critical interest of a person if violating that right would affect the critical interests of that person negatively. For example, a moral right not to be subject to torture is significant to the critical interests of a person because torture hurt critical interests in avoiding severe pain and in preserving bodily integrity. Now, the putative moral right to democracy does not appear to withstand the test that the critical interests of individual citizens are compromised if the duty to provide democratic institutions is violated. In fact, the shift from democratic to authoritarian rule would make no difference to most people, with regard to the enjoyment of private and public according to the studies cited above. The evidence in support of the claim that democratic institutions are important to the critical interests of individuals, equal statistical claims about the 'mean causal effects' on variables that represent valuable outcomes in the aggregate (Mahoney 2008). Typically, these effects are rather small. To illustrate, the mean difference in state repression between the least democratic state and the most democratic state is about $10 \%$ (or 0.4 or a five point scale) (Davenport 2004, p.551). This is consistent with the transition from authoritarian to democratic rule making no difference at all in some cases and with the difference being relevant to very few individuals in other cases. In any case, there is no inference from this observation that the violation of a moral right to democracy negatively affects the critical interests of every citizen. 
Provided that a condition for the existence of a moral right is that it significantly protects critical interests, in the sense that they would be undermined if the right is violated, it follows that a moral right to democracy cannot be justified by appeal to the positive benefits of democratic institutions on the critical interests of citizens.

The second worry is concerned with the relationship between a moral right to vote and a moral right to democracy. In truth, there is no inference from the fact that A has a moral right to democracy to the conclusion that A has a moral right to vote. Assuming that democratic institutions do have significant positive effects on the critical interests of individual citizens, these benefits accrue to every subject of democratic institutions, whether or not they are entitled to vote. It would thus make perfect sense to hold that some people have a moral right to democracy while not being morally entitled to vote. For example, children might have moral rights to democratic institutions even if they do not have moral rights to vote. The more important problem however is that the no-impact objection remains valid even if true that democratic institutions have significant positive effects. That is, my opportunity to vote is still extremely unlikely to make a difference to the protection of my critical interests. The claim that democratic institutions serve my critical interests is neither implied by nor premised on my opportunity to vote being instrumental to my critical interests. Thus, even if the argument for a moral right to democracy is correct, it would consequently be impermissible to infer that individual citizens have moral rights to vote.

The last worry is perhaps avoidable by modifying the argument for a moral right to vote. Instead of appealing to the instrumental importance of democratic institutions for the critical interests of citizens, we might appeal directly to the instrumental importance of voting rights. That would allow us to circumvent the objection that a moral right to vote cannot be derived from a moral right to democracy. Of course, the claim that voting rights are important to the critical interests of citizens also requires a different account of the interests involved. The point would be that the moral significance of democracy does not depend on it providing private and public goods but on it being the only means for the preservation of the 'regulative interests in citizenship' (Beitz 1989, p.100).

As citizens, we do not merely strive for goods such as health, education and physical integrity, but also put a high premium on our relationship to public institutions. The regulative interests in citizenship are either substantive or procedural. Substantive regulative interests depend on the outcomes of the democratic process, whereas procedural regulative interests depend on intrinsic features of the democratic process. Substantive regulative interests are similar to interests in private and public goods as they too depend on the outcomes of democratic institutions. For this reason they are discussed in this section, whereas arguments based on procedural interests are examined in the next section.

Three distinct views about the substantive regulative interests of citizenship are prominent. The first is that voting serves as a means for resolving disagreement and conflict. Political rights are essential because people typically disagree about the common good and the nature of our rights. The right to vote is the 'right of rights' as it provides an instrument for resolving such disagreements (Waldron 1999). A moral right to vote is justified by securing critical interests in the peaceful means for resolving conflicts about rights and goods. The second view is that political rights are essential to make public institutions 'responsive to one's own interests' (Christiano 2009, p.62). Responsiveness is in turn of importance to the individual as each person has a fundamental interest in feeling 'at home in the world'. The vote contributes to feeling "at home" in the negative sense of preventing a world that is shaped only by others and that is hostile to one's interests; the vote ensures that the world we inhabit is 
not one that 'corresponds in no way to one's own judgements' (Christiano 2009, p.62). The third view, lastly, departs from the assumption that everyone has a fundamental interest in equal social relations. Hence, the vote and political rights in general are justified because they represent the instruments for securing equal social relations. Only by means of an 'equal opportunity for influence' are citizens secured the means to counter policies that jeopardize the quality of social relations in society (Kolodny 2014).

However, the attempt to anchor moral voting rights in the substantive regulative interests of citizenship are not impervious to the no-impact objection. The objection holds that individual votes are unlikely to affect electoral outcomes and that individuals are therefore unlikely to promote their interests by means of voting. As it seems, the consequent objection, that the vote is ineffective in securing any individual interest that depend on the outcome of general elections, is applicable to the three arguments recounted above as well. Given that individual votes have 'no impact' on outcomes, it is mysterious how the right to vote could be instrumental to the preservation of individual interests in resolving disagreements about the provision or distribution of goods and rights, or to individual interests in feeling at home in the world, or in securing policies and laws that maintain equal social relations. Disagreements about the rights of $\mathrm{A}$ are neither more nor less responsive to the interests of $\mathrm{A}$ just because $\mathrm{A}$ is able to vote; the social relations of $\mathrm{A}$ are neither more nor less equal as a result of $\mathrm{A}$ being able to vote, and the social world is neither more nor less responsive to the judgments of A just because $\mathrm{A}$ is voting. If a single vote is unable to affect the result of general elections, then voting does not help any individual to secure an outcome that depends on the result of elections. The argument from the substantive regulative interests in citizenship thus fails to establish grounds for a moral right to vote.

\section{Interests in Procedures}

The moral right to vote is often defended by appeal to the intrinsic benefits it confers to what is above termed procedural regulative interests in citizenship. Indeed, it is often emphasized that the right to vote is unique in its ability to provide public recognition by allowing 'each person to consider that he is as worthy and important as every other member of the community' (Miller 1978, p.17). A similar view is elaborated on by the Constitutional Court of South Africa in its judgement on the voting rights of convicted and imprisoned citizens. The Court insisted that the right to vote of each citizen is of fundamental importance because 'the vote of each and every citizen is a badge of dignity and of personhood' (August and Another v. Electoral Commission and Others, CCT8/99 [1999]).

A negative and a positive version of the claim that voting rights are 'badges' of equal status can be distinguished. The positive version holds that voting rights confer equal status. The point is that voting rights are sufficient but not necessary conditions for equal moral status. By contrast, the negative version of the claim holds that equal status requires voting rights. As a consequence, to deny anyone the right to vote necessarily undermines the extent to which that person is respected as an equal. In what follows I show that neither the positive nor the negative version of the claim vindicates a moral right to vote.

The reasoning of the Constitutional Court of South Africa is that voting rights are badges of status that matter importantly to people. This represents the positive version of the claim since the value of the right to vote stems from the goods it provides, not from the bads it helps us avoid. The same understanding undergirds David Miller's remark that universal and equal 
rights of suffrage communicates respect for the equal dignity of all citizens. Miller argues that 'political equality allows each person to consider that he is as worthy and important as every other member of the community' (Miller 1978, p.14).

Since neither the South African Court nor Miller propose that voting rights are necessary for equal status, there is no contradiction involved in accepting their claims that voting rights are 'badges' of equality and 'allows' for equal worth, and to accept also that people without voting rights are publicly recognized as equals. After all, there may be other sources of dignity and other badges of equal status, as noted by Steven Wall (2007, p.431). Consider the appointment of members of the legislature by lot. Presumably, it is consistent with respect for equal status and dignity to grant each member an equal probability of being 'elected' by the lottery. Hence, voting rights turn out not to be necessary for equal status. The point then is not that voting rights are unable to secure equal moral status but only that moral voting rights do not strictly speaking follow from the premise that citizens have a critical interest in equal moral status. What does seem to follow is that the members of a political community have moral rights to public recognition as equals.

A stronger basis for moral voting rights is offered by the negative version of the argument according to which the denial of equal voting rights constitutes harm to fundamental interest. Following this view, equal voting rights are among the necessary preconditions for the protection of each person's interest in equal status. This view is defended by Jeremy Waldron who argues that to deny some people the right to vote represents an 'insult' to the equal status of the people excluded (Waldron 1999, p.239). Whenever there is inequality in the provision of political rights, the political system conveys the message that some people's interests are not equally worthy of attention. The more radical claim is that depriving a person of the vote amounts to a 'badge of slavery' because it denies her of 'the ability to control the conditions of their own existence and excludes them from the political community’ (Zaman 2015, p.236).

Just as the positive claim, the negative version of the argument from equal recognition appeals to individual interests that are independent of the extent to which the voter is able to employ the vote to influence electoral outcomes; the possession of the right to vote serves to protect fundamental interests in equal recognition even if voting turns out not to be effective for the purpose of affecting electoral outcomes. Here then surfaces a basis for moral voting rights that is impervious to the no-impact objection.

Even so, from the claim that voting rights are sufficient to equal moral status, and that recognition of equal moral status are among the critical interests of citizens, it does not strictly speaking follow that citizens have moral rights to vote. The conclusion supported by the negative argument is that equal rights to vote are required to secure interests in recognition as moral equals. But this conclusion is distinct from the claim that voting rights protect the critical interests of voters. To see the distinction, note that A's interest in the equal distribution of $\mathrm{X}$ does not entail that $\mathrm{A}$ has an interest in the provision of $\mathrm{X}$. For example, we may accept that to refuse A cake for no good reason is contrary to A's interest in equal status. And yet, to accept this point is not to accept that $\mathrm{A}$ has a right to cake but only that A has a right to treatment as an equal whenever cake is provided. As a consequence, the interest in equal recognition does not offer a basis for a moral right to vote as such. The moral right to an equal distribution of $\mathrm{X}$ neither depends on, nor is supportive of, the moral right to $\mathrm{X}$. To avoid the 'badge of slavery' a person must be treated as an equal. But the duty to treat a person as an equal does not entail that the person has a moral right to vote (see also Beitz 1989, p.6). 
A remarkable feature of the argument that voting rights are valued exclusively as means for public affirmation of equal status, is that he exercise of the vote does not appear important at all. After all, the right to vote confers equal recognition whether or not this right is put to use. But the notion that voting rights only serve our interests in equal recognition, is arguably to miss out on what is the basic political functions of rights to political participation. The vote is an essential precondition for democracy in large-scale societies because it is the instrument whereby collective decisions are made dependent on the participatory activities of people (Estlund 1990, p.414). Hence, moral reasons for voting rights should be able to explain not just why important interests are preserved by having the right to vote but also why important interests are preserved by the exercise of the vote.

\section{Interests in Collective Participation}

Perhaps, the opportunity to vote is important because it allows us to do engage in a particular kind of communal activity that is distinct both from the outcomes of participation or the recognition secured by rights to participation. Voting is important because it is acting together with others, a specific kind of 'action-in-concert'. Following Jacob, even a single vote is among the constitutive conditions of this particular kind of good - voting together with others. (Jacob 2015, p.70).

Does the value of voting together with others provide a basis for a moral right to vote consistent with the demands of the interest-theory of rights? Following the interest-theory, the moral right of $\mathrm{A}$ to $\mathrm{X}$ is conditioned by $\mathrm{X}$ being instrumental to the critical interests of $\mathrm{A}$. In order for the argument from the value of voting together with others to meet this condition, we must make plausible the claim that the critical interests of individuals are served by 'action-in-concert'.

Jacob explains the critical importance of voting together with others by pointing out that voting is an exercise of individual autonomy at the collective level. Individual autonomy is among the critical interests of the person and consists in the exercise of our capacity to reflect upon our preferences in light of second-order reasons. The right to vote permits each person to exercise this capacity collectively, together with others. Yet, from the claim that individual autonomy is a critical interest, it does not follow that voting is necessary for its preservation. In fact, there does seem to be a variety of situations where the right to reflect and to choose and to exercise autonomy is important, some of them arguably much more important than voting (in choices about our partners, jobs, housing, children, etcetera). This point remains valid even if recognized that voting represents an exercise of individual autonomy at the 'collective level'. After all, from the premise that individual autonomy is important, all that follows is that we have reason to preserve interest in individual autonomy, not that we have reason to preserve interests in the exercise of individual autonomy at the collective level. Jacob's claim that voting represents a collective application of autonomy is consequently insufficient to establish a moral right to vote.

In order to justify the moral right to vote, on the basis of the claim that voting serves interests in exercising individual autonomy at the collective level, it is necessary to assume that individuals have a specific critical interest in collective manifestations of their autonomy. The argument for the moral right to vote would be, then, that voting satisfies critical interests in doing things together with others that are also expressions of our individual autonomy. This is not the argument offered by Jacob, however. And for good reason, as it is vulnerable to a longstanding objection against putative individual rights to collective activities.

The objection is that there cannot be rights to objects that are collective in a certain sense of that term. Following Waldron (1987, p.310), it makes no sense to say that people have rights to 
'communal goods' such as 'fraternity, community or culture' because their 'enjoyment is primarily a property of the group' rather than of individual persons. The basic point, is that there can be no individual right to shared feelings. So, to the extent that the moral right to vote depends on the shared enjoyment of action-in-concert, it is simply inadequate as a justification of that right.

Perhaps, though, the point with action-in-concert is not the shared but individual enjoyment of this experience. It is true that the value of voting together with others depends on others taking part in the activity. But it is not necessarily true that the value of this activity is premised on others sharing the same feelings. Democracy is a collective enterprise in the sense that participation by others is needed for its realization, though not in the sense that the enjoyment of participation must be shared with others. The value of action-in-concert is thus possible to explain without falling prey to Waldron's objection against rights to communal goods.

The argument might still be vulnerable to the objection that it represents an attempt to defend individual rights to 'participatory goods'. In order to serve individual interests in action-in-concert it is clearly insufficient for others to respect the right to vote of the individual. The benefits of voting together with others is only satisfied to the extent that others have duties to actually participate together with you. Hence, the idea that the vote is a means for the preservation of interests in some communal activity would entail rights to the participation of others, which does not make much sense. The fact that $\mathrm{A}$ has an interest in the participation of B and C, clearly does not establish that B and $\mathrm{C}$ have duties to participate together with A (Réaume 1988).

However, Jacob does not defend the moral right to vote by appeal to the intrinsic importance of participation. The argument he offers is instead that voting together with others is a 'unique means' whereby citizens 'are treated as equals in their capacity as autonomous actors'. The rationale for the moral right to vote is, then, not just that it preserves individual interests in autonomy - even at the collective level - but more fundamentally that it preserves the interests of each person in 'respect of equal moral status' (Jacob 2015, p.70). What is crucial here, is Jacob insistence of the 'uniqueness' of voting in having the capacity to confer respect of each person as an equal; 'participation in formal democratic procedures is a unique means for the members of a political community to exercise autonomy on a collective level, in a way that treats all of them as equals' (Jacob 2015, p.71, emphasis added). The claim that voting is unique in that regard is essential since it means that the right to vote is truly necessary in order to confer respect of equal status to citizens. Whatever means are available for recognition of individual autonomy in other spheres of society or by other rights, none compares to the right to vote.

The uniqueness of the right to vote in its capacity to secure public affirmation of equal status is controversial, as observed previously. Moreover, the decisive objection against the argument Jacob offers is identical to the one directed against the argument from equal recognition. The claim that equal voting rights are required in order to confer equal recognition, only establishes a moral right to equal recognition, not a moral right to vote. From the fact that A must be granted the same rights to $\mathrm{B}$, in order not to suffer harm to critical interests in equal status, it follows that $\mathrm{A}$ is morally entitled to the same opportunities to vote as $\mathrm{B}$, but not that either A or B are morally entitled to vote.

\section{Collective Interests in Outcomes}

As already noted, democratic institutions are associated with outcomes that serve the critical interests of individuals. We also know by now that this observation does not justify a moral 
right to vote, both because the effect is not significant enough to the critical interests of each person and because the voting rights of each person might not make add significantly to these effects. These objections basically show that opportunities to vote do not adequately contribute to the preservation of the interests of rights-holders and that there is for that reason no basis to think that voting rights are instrumental to the critical interests of the individual.

However, the vote might contribute to the preservation of the interests people have in common - their collective interests. In this section I explain how to argue that the moral right to vote can be justified by collective interests and how to respond to important objections against it. Indeed, I conclude that the argument from collective interests is vulnerable to some of the objections and that the argument from equal recognition is needed in order to reinforce it. Together, the significance of collective interests in voting and the importance of the vote as a badge of equal status forms a two-step argument showing both why a moral right to vote exists and why it should be distributed inclusively.

The first step in this argument is to explain the concept of collective interests. One view is that it refers to the interests of groups qua groups. The interests are attributes of the group and not of its individual members. We sometimes speak about nations, peoples or even states in this vein and one way to make sense of it is to say that some groups are 'incorporated' in the sense that they are akin to moral agents (Jones 1999).

Now, this is not how we understand 'collective interests'. By collective interests we instead refer to the aggregate interests of members of a group. For example, provided that it is in the interest of several residents in a city that the park remains unexploited, their collective interests equals the aggregation of the interest of individuals in preserving the park. The notion of collective interests so defined does not signify interests distinct from the individuals involved. Indeed, to talk about 'collective interests' is a mere 'facon parler' (Raz 1986, p.208) that is fully consistent with 'individualistic' justifications of rights that require reasons grounded in the interests of individual rights-bearers (Cruft 2005, p.36). This understanding of collective interests is congruent also with Bentham's dictum that 'individual interests are the only real interests' (Bentham 1931, p.144).

The second step is to specify the nature of the relevant collective interest that justifies moral voting rights. An obvious contender is the interest to live in a political entity where collective decisions are made by its members. If individual members have interests in 'self-rule', they have collective interests in self-rule that potentially justifies moral voting rights. The consequent view is tantamount to the belief in 'popular sovereignty' or the claim that the collective unit of the people is sovereign and self-ruling only if its members 'enacts the laws by which they are to be bound' (Thompson 2005, p.245). The basis for the moral right of individuals to vote consequently derives from the more fundamental right of peoples to rule themselves and to decide their own destiny. Dwight (2004, p.161) goes further and argues that voting rights are necessarily premised on such interests; 'the existence of a moral right to vote implies the existence of collective moral right to self-determination'.

Now, there is big step missing in arguments to the effect that collective interests in selfdetermination, self-rule or popular sovereignty (I use the terms synonymously) justify moral voting rights for individual members. The problem overlooked by advocates of selfdetermination as the basis for democratic rights is that self-determination entails both the power and liberty to make decisions; that is, both the capacity and freedom to rule (Morss 2009). Thus, rights to self-determination includes the liberty to decide whether voting should be practiced or not. This point is acknowledged by Jeremy Waldron, noting that peoples exercising the right to decide their political destiny should be able to consider 'various forms of 
government on the menu' (Waldron 1999, p.255). The implication is that individual moral rights to vote in general elections cannot be grounded in the collective interests of peoples to self-rule. At most, such interests justify moral rights to vote in the decision about the political status of the unit (Altman and Wellman 2009).

A different route is to re-introduce the notion that democratic institutions promote private and public goods that serve the interests of individuals. As shown in section one, this view faces two challenges. The first is that the causal effect of democratic institutions are not significant enough to the critical interests of each individual. The second is that the right to vote of each individual does not contribute significantly to the causal effect of democratic institutions - because of the 'no-impact' objection.

The invocation of collective interests is helpful in addressing the first issue. Although the contribution of democratic institutions to the interests of each person in health, education, peace and physical integrity is small, the aggregate contribution of democratic institutions to these ends is significant. By focusing on the collective interests of the members of a nation, rather than the interests of each individual taken separately, it is clear that the consequences of democratic institutions are substantial.

Nonetheless, it is not immediately clear if collective interests defined as the aggregate interests of members of groups justify moral rights. In fact, it is contrary to the interest-theory to conclude that large aggregate effects are sufficient to justify moral rights. As already noted, what distinguishes rights from other morally desirable states of affairs is that they protect some 'critical' aspect of an individual's well-being (Raz 1986). The challenge for the proposition that collective interests justify moral rights is to explain why they are 'critical' even though the individual interests that constitute them are not critical taken separately.

One suggestion is that collective interest are important exactly because they are shared with others. Perhaps the importance of democracy to a single individual is not sufficient to justify duties in others to secure a moral right to democracy. But if the interests served by democratic institutions are shared together with others, these collective interests arguably gain significance. The basis for moral rights in democracy then is that democracy institutions protect collective interests.

An objection to this account is that it is questionable that interests are more important just because they are shared with others. As pointed out by David Miller (2002 p.184), trivial interests do not become more important simply because many people have them. For example, many people have an interest in watching football and the fact that many people share this interest does not make it any less trivial. Now, moral rights are premised on them serving the 'critical' interests of the rights-bearer which means that moral rights exists only to protect interests that are basic or fundamental to the wellbeing of human beings. Given an account of what counts as basic interest, as specified by for example the capability approach, it is clear that health is among the basic interest of individuals while watching football is not. In order for some collective interest to be of critical importance, it must be concerned with some 'basic' aspect of individual wellbeing. Thus, the point with the appeal to collective interests is not to say that the trivial interests of individuals are becoming 'critical' in the relevant sense just because they are shared by the many. The point with the appeal to collective interests is rather that the causal effects of democratic institutions are quite significant to collective interests even if not significant enough to individual interests. If moral rights can be justified on the basis of them being significant to the preservation of collective interests, this observation is crucial. The notion of collective interests helps overcome the first obstacle towards a justification of a moral right to vote. 
The second hurdle is that reasons supportive of a moral right to democracy fail to generate reasons supportive of moral voting rights. The problem is that it does not follow from the claim that the collective interests of citizens benefit significantly from democratic institutions that any particular citizen is morally entitled to vote. This is the familiar no-impact objection; the right to vote of a single citizen is not instrumental to the preservation of collective interests.

The problem here is not that voting rights as such do not have a role to play in the argument. Certainly, if democratic institutions have positive effects, and if voting rights are among the necessary requirements of democratic institutions, voting rights do contribute to the positive effect. The problem is rather about the derivation of duties towards specific individuals. From the claim that voting rights do contribute significantly to critical interests (by virtue of being collective interests) it is impossible to infer that the voting rights of every individual citizen is significant and consequently impossible to conclude that individual citizens are morally entitled to vote. All the argument shows is that the voting rights of some sub-set of the citizenry is significant. But this precise point might also indicate a solution. If the right to vote some sub-set of the citizenry is necessary for the preservation of collective interests, we might as well conclude that the moral right to vote applies only to the sub-set. Instead of trying, in vain, to demonstrate that the instrumental importance of democratic institutions to human wellbeing is offering reasons for the moral right to vote of every individual citizen, we should remain satisfied with the conclusion that the moral right to vote applies only to a sub-set of the citizenry. Incidentally, this concession is in tune with the long-standing tradition in empirical work to define the threshold of voting rights necessary for democracy as considerably lower than what is usually understood by 'universal suffrage'. For example, following one of the most popular datasets of democracy (Polity IV), suffrage rights for $20 \%$ are sufficient for democracy (Marshall and Jaggers 2002, p.26). Hence, the intermediate conclusion is that the moral right to vote by a sub-set of citizens is justified by them serving the critical interests of all of them.

But does it make sense to speak of the moral right to vote of a sub-set of citizens? Usually, moral rights are owed to specific individuals, not to sub-sets of groups. The claim that $\mathrm{A}$ has a right to $\mathrm{X}$ is to say that the duties of others are 'owed to' A as a rightsholder (Buchanan 2005, 72). The problem is one of the identity of the rights-holder. Duties are owed to specific persons, not to an abstract 'sub-set' of citizens wherein no identifiable individual belongs.

Yet, the position defended here does not have to deny the existence of duties to identifiable individuals. The moral right of a sub-set to vote is consistent with every citizen being owed a moral duty to secure the vote to the members of the sub-set; the moral right to vote correspond to duties owed to every citizen despite the fact that it only takes the right to vote of a sub-set of them to discharge these duties. In other words, every citizen holds a moral right to the effect that a sub-set of them are able to vote.

A distinct but related objection is that the position developed here dissolves the identity between the rights-holder and the interests that justifies the right. The interest-theory of moral rights holds that the moral rights of A are premised on them making a significance contribution to the critical interests of A. Moral rights are consequently presumed to belong to the agent whose interests are preserved by having the right. This requirement is violated by the claim that the moral right to vote of a sub-set of citizens serves to protect the interests of citizens generally.

Now, there is a difference between the claim that the moral rights of $\mathrm{A}$ and $\mathrm{B}$ are justified by them serving the critical interests of $\mathrm{C}$ and $\mathrm{D}$ and the claim that the moral rights of $\mathrm{A}$ and $\mathrm{B}$ are justified by them serving the critical interests of A, B, C and D. Only the latter situation is relevant in this context, as the voting rights are believed to serve the collective interests of all citizens. 
In addition, the interest-theory of moral rights evidently allows for moral rights to be justified by the critical interest of others than the rights-holders themselves. Following Joseph Raz, certain rights, such as rights to free speech, are moral rights because they benefit 'not only to those who have this right' but also because they benefit the public at large. Thus, the basis for moral rights derives either from the interest of others or from the interest of the rights-holder ( $\operatorname{Raz} 1994, \mathrm{p}, 54$ ). To accept this point, is to accept a slight modification in the original formulation of the interest-theory. The implication is that the moral right to vote of some citizens can be justified by them being instrumental to the critical interests of citizens generally.

The argument for the moral right to vote is, then, that opportunities to vote by a sub-set of citizens contributes significantly to the preservation of the critical interests of citizens at large. Voting rights contribute to the interests of citizens because the voting rights of some sub-set of them is among the necessary preconditions for them to enjoy the outcomes of democratic institutions. The contribution is significant enough because voting makes a substantial difference to the collective interests of citizens.

A final objection, however, is that moral voting rights of a sub-set of citizens is a far cry from the democratic claim that every member of the association should be entitled to vote. Hence, the argument for the moral right to vote presented appears to allow for the continued exclusion of large segments of the population and clearly do not offer a basis for the enfranchisement of the various categories of people that currently lack voting rights in democracies.

What this objection shows is that the grounds for a moral right to vote are distinct from the grounds for an inclusive moral right to vote. The argument above explains why there is a moral right to vote, not why the moral right to vote should be inclusive. In so far as we are concerned with the inclusiveness of the moral right to vote, other normative considerations apply. Indeed, we observed in section three that interests in public recognition of equal moral status are pertinent to the inclusiveness of voting rights. Given critical interest in not being treated as inferior to others in moral status, inclusive moral rights to vote are of great significance. As argued previously, interests in public recognition do not justify moral rights to vote, though they serve to explain the moral importance of inclusion once moral right to vote have been shown to exist.

\section{Conclusions}

Following the original formulation of the interest-theory of rights, the moral rights of a person are premised on the duties of others serving the interest of the rights-holder. A precondition for a moral right to vote is hence that it is instrumental to the preservation of the interests of the rights-holder. In the first sections of this paper, I show that previous theories are unable to satisfy this requirement and are therefore unable to substantiate a moral right to vote.

The view defended here is that moral rights to vote can be justified if acknowledged that they contribute to the preservation of the critical interests of others, if these interests are conceptualized as collective interests and if the consequent right to vote is attributed to a subset of citizens. These considerations are sufficient to establish the existence of moral voting rights though they do not suffice to establish inclusive moral rights to vote. In order to achieve that we need appeal to interests in the public affirmation of equal status. The basis for moral 
rights to vote in a democracy accordingly depend both on collective interest in the outcomes of democratic institutions and on individual interest in the recognition conferred by democratic institutions themselves.

Open Access This article is distributed under the terms of the Creative Commons Attribution 4.0 International License (http://creativecommons.org/licenses/by/4.0/), which permits unrestricted use, distribution, and reproduction in any medium, provided you give appropriate credit to the original author(s) and the source, provide a link to the Creative Commons license, and indicate if changes were made.

\section{References}

Acemoglu D, Naidu S, Restrepo P, Robinson JA (2014) Democracy does cause growth. NBER working paper no. 20004

Altman A, Wellman C (2009) A liberal theory of international justice. Oxford University Press, Oxford

Beitz C (1989) Political equality. Princeton University Press, New Jersey

Bentham J (1931 [1840]) The theory of legislation. Routledge \& Kegan Paul, London

Buchanan A (2005) Equality and human rights. Poli Philos Econ 4:69-90

Christiano T (2009) The constitution of equality. Oxford University Press, Oxford

Christiano T (2011) An instrumental argument for a human right to democracy. Philos Public Aff 39:142-176

Cruft R (2005) Human rights and positive duties. Ethics Int Aff 19:29-37

Dafoe A, Oneal JR, Russett B (2013) The Democratic Peace: Weighing the Evidence and Cautious Inference International Studies Quarterly 57:201-214

Dahl R (1989) Democracy and its critics. Yale University Press, New Haven

Davenport C, Armstrong D (2004) Democracy and the violation of human rights: a statistical analysis from 1976 to 1996. Am J Polit Sci 48:538-554

Estlund D (1990) Democracy without preference. Philo Rev 99:397-423

Gerring J, Thacker SC, Alfaro R (2012) Democracy and human development. J Politics 74:1-17

Geys B (2006) Rational' theories of voter turnout. Political Stud Rev 4:16-35

Griffin J (2008) Human rights. Oxford University Press, Oxford

Jacob D (2015) Every vote counts: equality, autonomy, and the moral value of democratic decision-making. Res Publica 21:61-75

Jones P (1999) Human rights, group rights, and peoples rights. Hum Rights Q 21:80-107

Kamm F (2002) Rights. In: Coleman J, Shapiro S (eds) The Oxford handbook of jurisprudence and philosophy of law. Oxford University Press, Oxford, pp 476-513

Kolodny N (2014) Rule over none II: social equality and the justification of democracy. Philos Public Aff 42:287-336

Lyons D (1969) Rights, claimants, and beneficiaries. Am Philos Q 6:173-185

Mahoney J (2008) Toward a unified theory of causality. Comp Pol Stud 41:412-436

Marshall M, Jaggers K (2002) Polity IV Project. University of Maryland, Political Regime Characteristics and Transitions. Dataset Users' Manual

Mesquita B de, Siverson RM, Morrow JD (2003) The logic of political survival. MIT Press, Cambridge

Miller D (1978) Democracy and social justice. Br J Polit Sci 8:1-19

Miller D (2002) Group rights, human rights and citizenship. Eur J Philos 10:178-195

Morss J (2009) The legal relations of collectives: belated insights from Hohfeld. Leiden J Int Law 22:289-305

Newman D (2004) Collective interests and collective rights. Am J Jurisprud 49:127-163

Raz J (1986) The morality of freedom. Clarendon Press, Oxford

Raz J (1994) Ethics in the public domain. Clarendon Press, Oxford

Réaume D (1988) Individuals, groups, and rights to public goods. Univ Tor Law J 38:1-41

Robeyns I (2009) Capability approach. In: Peil J, Van Staveren I (eds) Handbook of economics and ethics. Edwar Elgar, Cheltenham, pp 39-46

Thompson DF (2005) Democracy in time: Popular Sovereignty and temporal representation. Constellations 12:245-261

Waldron J (1987) Can communal goods be human rights? European Journal of Sociology 28: 296-322

Waldron J (1999) Law and disagreement. Cambridge University Press, Cambridge

Wall S (2007) Democracy and equality. Philos Q 57:417-438

Weale A (2007) Democracy. Bassingstoke: Palgrave Macmillan

Zaman S (2015) Violence and exclusion: felon disenfranchisement as a badge of slavery. Columbia Hum Rights Law Rev 46:233-277 